\title{
A Postcolonial Reading of the Triumphant Entry
}

\author{
Adegbite Deborah Doyinsola ${ }^{1}$, Adegbite Olusola Deborah ${ }^{2}$ \\ ${ }^{1}$ Adeleke University, Ede, Nigeria \\ ${ }^{2}$ Bethel Institute of Theology, Gbongan, Nigeria \\ Email: adegbitedebbie@yahoo.com, sola.adegbite@gmail.com
}

Received 5 June 2015; accepted 22 June 2015; published 30 June 2015

Copyright (C) 2015 by authors and OALib.

This work is licensed under the Creative Commons Attribution International License (CC BY).

http://creativecommons.org/licenses/by/4.0/

(c) (i) Open Access

\begin{abstract}
This paper explores the Matthean version of the Triumphant Entry from a Nigerian postcolonial perspective. The methodology used is the exegesis of the passage using a Reader Response criticism to understand the contextual and typological contemporary meanings of the passage. The result showed that the colonial harbinger of the gospel message introduced a colonized gospel that robbed the people of the liberation they ought to experience through the gospel.
\end{abstract}

\section{Keywords}

Postcolonial Criticism, Triumphant Entry, Evangelism, Theology, Christianity, Nigeria

Subject Areas: Education, History, Philosophy

\section{Introduction}

Although this passage focuses on Matthew's rendering of the story, divergences with the other gospels are not too different. The immediate preceding and following stories are different for all the gospels but within the stories themselves, the differences are as follows. First is that only Matthew seems to suggest two animals: an ass and its young while the other gospels mention just an ass. Beare and Tasker suggest Matthew's rendering to be an employment of Hebrew Parallelism where the second sentence is a repetition of the first in a slightly different way [1] [2]. As Jesus entered into Jerusalem, only Luke added that some Pharisees were unhappy that the disciples hailed Jesus and then told Jesus to rebuke the disciples but Jesus replied that if the disciples should keep silent, stones would cry out in protest (Lk 19: 40). John's uniqueness, which is in consonance with his efforts to make us believe by what he has chosen to write down, is that the disciples at first does not understand the meaning of the triumphant entry until Jesus is glorified, but afterwards they discover that scriptures are fulfilled in Jesus (Jh 12: 16). The time at which Jesus enters Jerusalem is in the evening in Mark but Matthew suggests the morning time since Jesus still has time to cleanse the temple that day. Matthew's conclusion, which is dif- 
ferent from others, is a question raised among the multitude again asking who has entered into the city. It is the same multitude that acknowledges that it is Jesus, the prophet from Nazareth of Galilee (Mt 21: 11). This seems to be in line with the thought that Matthew's gospel often wants to show that Jesus is King.

For this paper, Matthew's account, for no special reason, would be used and other information from other gospels would be harnessed as needed.

\section{Exegesis and Typological Reading of the Text}

A $\pi \varepsilon \sigma \tau \varepsilon i \lambda \varepsilon v$ : The word from which we get "apostle" describes the mission of the two disciples. These two, like evangelists have been specifically sent on a special mission which means a lot to how we interpret Jesus' identity and ministry. They were sent to the village opposite them. For the purposes of colonial and postcolonial readings, the word "village" ( $\kappa \omega \mu \eta)$ becomes important. The Greek word $\kappa \alpha \tau \varepsilon v \alpha v \tau \imath$ rendered "opposite" could also mean "in the sight of", that is the village that you can see over there. This is consistent with Jesus' charge to be witnesses in "Jerusalem, Samaria, Judea and all parts of the world". They were sent to their immediate neighbourhood.

"You will find": Through Jesus' foresight [3] or perhaps apreplanned arrangement [4], Jesus already knew that those animals were there waiting to be loosed. Like Zacchaeus who went up the tree looking to see Jesus, it turned out that Jesus was in fact the one looking for him. There was this deep certainty that there was such a bound animal even before the disciples got there. No possibility was given to the fact that the animal could have escaped or that the owner has freed it for other purposes.

"A donkey that has been bound": the Greek phraseology for the verb "to bind" here is the participle perfect passive feminine singular accusative form of the verb $\delta \varepsilon \omega$. Interestingly the perfect in Greek has a different scope of meaning from the perfect in English. Daniel Wallace mentions succinctly that "The perfect is used less frequently than the present, aorist, future, or imperfect; when it is used, there is usually a deliberate choice on the part of the writer" [5]. In short, the perfect tense in Greek means "a present state resulting from a past action" [6]. The implication that this has for the bound animals is that their binding was not an accident. It was some unknown earlier deliberate action that caused the animals to be bound now. Their present state was warranted by an earlier action.

The next action that follows, however, is that, Jesus says, using the aorist tense now. "At this particular instant you, loose the animals [7] and lead (or bring) them to me". The verb $\dot{\alpha} \gamma \omega$ is used to say this which means "I lead" or "I bring" (a term used in evangelistic contexts to mean to lead someone to Christ). Nevertheless this is an act of liberation despite the previous action that warranted their binding. The perfect tense of the Greek described earlier "does not exclude the notion of a completed act; rather it focuses on the resultant state" [8] but Jesus decides not leave the animals bound (regardless the justifications that there might be for binding them). Jesus also does not attempt to change that past of being bound, but rather proceeds to rewrite the future such that the animals would not stay bound. In similitude to the words of the song "Amazing Grace", these donkeys could say "once they were bound, but now they are free".

However, the act of liberation does not come without its obstacles. The authority by which the disciples loose the animals is subject to questioning. People asked, "Why are you loosing it?" (Lk 19: 31). An actual confrontation against the action of loosing was not recorded in Matthew but Mark and Luke records that some people in whose presence the disciples wanted to loose the colt actually questioned the disciples. Gratefully Jesus had already told the disciples what to say if such need arose. The disciples were to respond thus, "The Lord has need of them', and immediately he will send them" (Mt 21:3). This statement is to authorize or validate the authority of the disciples to loose the animals. When the appropriate authority, which is the Lord's, backs up their action, the opposing party would have no choice than to immediately release the animals for the Lord's use.

It must be noted further that the reason for loosing the animals is not and must not be divorced from the purpose for which they are loosed. It would make no sense to loosen the animals and ignore the purpose for which they are loosed. When the animals are loosed, Jesus said to bring them to him (Mt 21: 2). In addition, if anyone questions the disciples for loosing the animals, the disciples are to stand their ground saying that the Lord has need of the animals. In essence, the identity and status of Jesus in this action is not to be taken lightly. Jesus is the reason why they can be loosed; Jesus' need is also the reason for which they are loosed.

But asides from the validation Jesus places on the disciples' authority to loose the animals, Matthew endorses the action further by claiming that all this was done to fulfil an earlier prophecy found in Zechariah 9. This con- 
nection to Old Testament prophecy is found only in Matthew and is a characteristic of his gospel where only he in the gospels often makes connections with earlier Old Testament prophecies. Matthew's gospel is "even more explicit about the fulfilment of Old Testament Prophecy" [9]. Similarly as we would find later on in a colonial context, there is the religious (prophetic) justification for colonial activity in Africa.

Then having brought the animals to Jesus, the disciples put their clothes on the animals and Jesus sat on them. Likewise the great multitude also spread their clothes on the floor for Jesus and the donkey to tread upon. This entry into Jerusalem plays upon the imagery of Alexander the Great coming into Jerusalem. Alexander had come on a war horse during a military campaign. The people feared that Alexander would destroy them but luckily for them, God had already told the prayerful High Priest at the time to dress in his priestly regalia to meet Alexander. Upon seeing the High Priest, Alexander got off his horse and bowed down. The people around wondered why Alexander bowed down to the High Priest but his response, Alexander's, was that it was to the God who had ordained the High Priest that he bowed down because in his several battles, he saw the High Priest standing by him to fight and help him overcome in wars. Hence Alexander dealt peacefully with Jerusalem [10].

In comparison with Jesus [11], Jesus on the other hand comes into the city with a donkey. The people understood his mission to take over the government as Alexander had done in order to establish true peace and illuminate the people. Both entries into Jerusalem are welcome by the people and had been ordained by God. The people recognized great potential, political potential, in the entry of Jesus into Jerusalem so they hailed him as such.

One would have thought that the liberation Jesus brings to the donkey would be to set it free so that it is no longer a beast of burden. But Jesus uses the principle of demonic possession he mentions in Matthew 12: 43-45 that when an evil spirit is cast out of a person, the evil spirit becomes restless and wants to come back to possess that person. But when it comes back, finding it empty, the spirit comes with seven other more wicked spirits to live in such a person. In other words, having been freed from one demonic possession, one has to find another spirit, the Holy Spirit in this case, to take up that space or else the evil spirit would return. In a similar fashion, when this colt is relieved of a master, of a kind of possession, it needs to be repossessed by something else lest it goes back to the former state (or even a worse state than the one it was delivered from). This is to say that each person or nation must have something governing them; no human life can be empty without a master. So having released the donkey from its previous burden and bondage, Jesus sits on it as the new burden that it should bear.

By submitting itself to be used by Jesus, to be a Christopher [12], the honour that the donkey receives is only because Jesus that sat on it. On no ordinary day would a donkey receive such honour from people. It even wore human clothes and stepped on human clothes, the red carpet of that world. Horses on the other hand are already accustomed to and are often used for such honourable processions. Who would have thought that a donkey, a lowly animal, a beast of burden could ever be glorified?

Alongside the honour the donkey receives, Jesus too who had sat on it received praise. The proclamation of the multitude was indeed a political statement as to who they thought Jesus was and what he was going to do to alleviate their political oppression under the empire. There were people who further questioned Jesus' identity saying "who is this?" But his identity was also further reinforced, "This is Jesus, the prophet from Nazareth of Galilee" (Mt 21: 10-11).

\section{A Colonialist and Postcolonialist Typological Reading}

In the colonizer mentality, the African as the colt has been bound by its slavery to mundane, fetish, primitive ideas of worshipping stones, clay, iron, trees and rivers. Hence the colonizer came to civilize and liberate the African from its bondage as prophesied in Isaiah 49:6 that they will be a light to the Gentiles. But asides the need to be enlightened, just like how Jesus saw the animal not to be just a beast of burden but as an animal to be honoured, the colonizer has also spotted other potential in the African. The African could be an animal on whose backs the colonizer and slave master can sit and control, and in controlling, the colonizer can make fame and wealth for the colonizer. The Master's mission to evangelise becomes an important entrée to these ulterior motives. Or perhaps it could have been that while evangelising, other economic opportunities which were not pre-planned opened up. Indeed, along with the colonizer came Christianity as a religion. Truly, "missionary propaganda from its inception was inextricably bound up with political considerations" [13].

The evangelists in the Bible context although go to Bethphage on the Master's order to loose the colt; the colonizer goes on the Master's order alongside their own personal interests. Like there was the certainty that the 
donkey was there waiting for Jesus, the colonizers also marched into Africa with pre-notions of a definitely bound, oppressed people from which nothing good could proceed without their (colonizer's) help although there was no concrete evidence for this. Yet their rationale had to have its justifications. This led to terms like "the dark continent" to describe Africa. They were the primitive people of whom David Hume's work on Miracles describes that "the testimony in favour of miracles [which is common among Africans] usually comes from uneducated people who have lived in far off places at time in ignorant and barbarous nations" [14]. These constitute presumptions of the colonizer.

Furthermore the colonizer's presumptions, in the words of Olutayo and Omobowale, is that the colonial period was characterized by "the understanding of Africa was inhibited by four great denials, including the denial of history, the denial of science, the denial of poetry, and the denial of philosophy (including religious philosophy)" [15]. Hence the colonizer assumed the role of one to bring light to the dark people on the basis of the Denial Theory Rationale. These four denials are only some of the rationale for which Africans were thought of as inferior. Others included ideas like that because the Africans were dark in skin, hence they must necessarily be dark in their minds. They were also relatively shorter than the European hence somehow genetically inferior. The climate was largely conducive for living hence they had no climatic challenges that could have improved their intellect. Unfortunately though, for both the colonizer and the colonized, Africa was a dark continent only in the minds of the colonizer who did not know about Africans and yet could not be bothered to humbly learn about and learn from them. The evangelists forgot that evangelising to foreigners has a different dimension to it; Jesus gave an example when he talked to the Samaritan Woman at the well. Instead of coming from a privileged position of being a male and a Jew, he came rather from a humble position. He was expressed his need so he asked, also as an icebreaker, "Give me a drink" (John 4: 7). The woman recognized the awkwardness of the reversal of the "normal" social position so she replied, "How is it that you, being a (male) Jew, ask a drink from me, a Samaritan woman?" (Jhn 4: 9) [16]. Unfortunately in the African context, this humble and more humane approach in dealing with the foreign people was inhibited by the alternative agendas the evangelists had.

Moreover in the colonial phase, "To British officers and ambitious soldiers, the colonial wars opened great opportunities to rise in the service, become celebrities at home, and administer large areas and numbers of colonial subjects" [17]. It was on this note that Lord Frederick Lugard became popular in Nigeria's history. The instruction to loose the colt and bring it to Jesus was obeyed but their response to the people who asked "why do you loose it?" is now distorted. It is not only the Master that needs the colt but also the evangelists sent to loose it. "We all need the donkey, the master and us." The selfish purpose for loosing the animal together with Jesus' command becomes the justification for what the colonizers do to the donkey afterwards.

After loosing the donkey, it was supposed to be brought to Jesus for Jesus alone to use. But in the colonial context, loosing the donkey from its previous owner led to the colonizer lording itself over the donkey together with Jesus making a double burden to bear. Those that would not allow the colonizer to ride on their backs were killed [18]. If anyone asked, "who is this that rides gallantly on the donkey?" as they had asked in the triumphant entry (Mt 21: 10), the response is in the words similar to Stephen Selmon's. The response is, "It is the colonial power the one that "inscribes itself onto the body and space of its Others and [even now] which continues as an often occulted tradition into the modern theatre of neo-colonialist international relations"' [19]. In other words, the colonial master has to reinforce its identity and authority as Jesus' identity was impressed into the minds of the audience by the people.

But what happened to the colonial donkey afterwards? The colonial masters used it. This led to continued indirect slavery, economic exploitation, religious bigotry, political destabilization among many other ills. The honour it was supposed to have by having Jesus on it was turned to horror because the colonial masters rode with Jesus on the donkeys' backs. It is indeed not possible to serve both God and Mammon because when these big elephants fight, it is the grass underneath that suffers the most.

The characteristics of a natural donkey add a very interesting dimension to the aforementioned. The ones relevant to the current discussion are selected. Apart from being strong animals, and therefore used as beasts of burden, donkeys are also intelligent. They also cannot be forced to do something it considers unsafe [20]. The biblical evidence of this latter point comes from Balaam's story (Num 22: 22-40). In this story, the donkey saw the angel of the Lord in the way but Balaam did not. For this reason, the donkey refused to move further. Balaam was infuriated until the donkey spoke of it and God opened the eyes of Balaam to see the angel that would have killed him. Also, donkeys require that they can trust their owners and be protected by the owners. Only after this can they patiently learn what their owners want from them. 
The donkey willingly gave itself over to Jesus to be used for the master's purpose. But it is not surprising that the colonial donkey did not blindly follow the colonizer since the colonizer's purpose was unsafe and contrary to Jesus the master's purpose. But the severe violence inflicted on the colonial donkey could not be resisted for too long. Their will to remain independent soon fell apart.

A question that has not been raised or answered is the aftermath of the donkey after the Triumphant Entry. Did it go back to its former owner? Or the disciples kept it afterwards? Or did it wander away? The answer is not certain. But the aftermath of the colonial donkey is readily obvious to everyone. The divide and rule, and violent methods of the colonial rulers are described by Toyin Falola as the following, "British rule created a government that could not be trusted. The lack of trust became mutual: colonial officers did not trust the citizens they governed. The successive Nigerian governments that followed the colonial government have adopted a similar approach. Violence continues to mediate the relationship between the rulers and their subjects" [21].

But to lay blame on the colonial enterprise for present dilemmas would be a greater mistake. As Grundy says, "To blame the colonialist powers for Africa's underdevelopment suffers, objectively, from the weaknesses of most monocausal theories" [22]. Like the donkey, Jesus did not care to bother about the past of bondage, but worked out a better future despite the donkey's past or intended future of its condemnation to burden bearing. This is the better future that we too now must work out in line with Jesus' plan not the colonizer's plan. This future is one that has evolved from burden bearing to only Christ bearing.

The next steps we need to take therefore could as well be what Jesus does next in Matthew's gospel, "The Cleansing of the Temple" [23] (Mt 21: 12ff). This can be a starting point. Otherwise, we might want to follow Luke's arrangement, Jesus wept over Jerusalem before cleansing the temple (Lk 19: 41ff, 45ff). Following Luke's arrangement, Jesus wept over Jerusalem having realised the flaws of its inhabitants. He uncovers their past errors and weeps over the calamity that would befall them in the future. His weeping is not really just because of their past mistakes but their failure to recognize the time of their visitation in which they could have worked out a better future for themselves. Such retribution even for a postcolonial context might not be avoidable, in fact even now the perpetuating violence and corruption provides such evidence.

However, this calamity (present or future) that would befall them however still was not an excuse for Jesus not to do something about the present. The temple that was corrupted still had to be cleansed, at least while Jesus was there. So after recognising the problems with them, Jesus goes to the temple and begins to rectify them, using words and actions to effect change. He also teaches and heals them (Mt 21: 14).

In the Nigerian context, Peter Cunliffe-Jones has this to say about the interim government of President Jonathan after President Yar'Adua's demise, "To many outside the country, the uncertainty caused by Yar'Adua's collapse was alarming; the sign of a country once more on the verge of breaking apart. To me, the way the situation had been handled-peacefully, with a transfer of power without resort to violence and following popular pressure-was an encouraging sign". The same, perhaps, can be said of the March 2015 elections. In the light of this hope, it is time to regain the glory for the once-colonized donkey and transform it to a Jesus-only donkey, from a burden bearer to an only Christ bearing donkey.

\section{Conclusions}

So far, this paper has tried to exegete the triumphant entry its own context as well as a postcolonial Nigerian context. The former exegesis concentrated on key points on the status of the donkey, the nature of the evangelists, the purpose and outcome of loosing the donkey. The latter exegesis also looked at these same points with reference to colonialism. Although a donkey is a beast of burden, Jesus made it eligible for honour only if he was to sit on it. When other masters like colonial masters sit on the donkey alongside Jesus, the donkey can only experience horror.

In its own context, we have seen how the fate of a donkey was changed from a beast of burden to a honourable donkey by surrendering itself to a new master, Jesus. We have also seen how in our postcolonial context, the fate of Nigerians as a donkey has been rendered more miserable because it surrenders to two masters, Jesus and the Colonizer. Although Jesus had said, "Come unto me all you that labour and are heavy laden and I will give you rest. Take my yoke upon you and learn of me; for I am meek and lowly in heart; and you will find rest for your souls. For my yoke is easy and my burden is light" (Mt 11: 28-30), we had not experienced such rest. As a result, the conclusion in this paper has been to learn from the donkey's fate in the Triumphant Entry. We are to drive out the illegal masters and make Jesus the one and only true master. Yes, we must make sure that it 
is only the Jesus burden that we allow our backs carry as it is the one that comes with honour. All other burdens must be rejected; they must be shaken off, especially the colonizer's burden.

\section{References}

[1] Beare, F.W. (1981) The Gospel According to Saint Matthew. Blackwell, Oxford, 413.

[2] Tasker, V.G. (1961) The Gospel According to Matthew. Tyndale Press, London, 198.

[3] Beare, F.W. (1981) The Gospel According to Saint Matthew. Blackwell, Oxford, 414.

[4] Smith, D. (1908) The Gospel According to St Matthew. The Westminster Press, London, 170.

[5] Wallace, D. (1996) Greek Grammar: Beyond the Basics. Zondervan, Michigan, 573.

[6] Wenham, J.W. (1988) The Elements of New Testament Greek. Cambridge University Press, Cambridge, 139.

[7] The italicised words "animals" and "them" are not in the Greek. The Greek simply reads "Having loosed, bring to me..."

[8] Wallace, D. (1996) Greek Grammar: Beyond the Basics. Zondervan, Michigan, 575.

[9] Lace, J., Ed. (1965) Understanding the New Testament. Cambridge University Press, Cambridge, 76.

[10] Alexander and the Jews. www.aish.com

[11] Ehrhardt, A. (1964) The Framework of the New Testament Stories. Manchester University Press, Manchester.

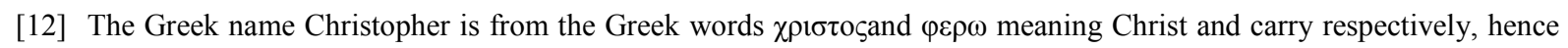
the names means Christ bearer.

[13] Ayandele, E.A. (1966) The Missionary Impact of Modern Nigeria. Longman Group Ltd., London, 1842-1914.

[14] Davies, B. (1993) An Introduction to the Philosophy of Religion. Oxford University Press, Oxford, 202.

[15] Olutayo, A. and Omobowale, A. (2007) Capitalism, Globalisation and the Underdevelopment Process in Africa: History in Perpetuity. Africa Development, 32, 100.

[16] Jews and Samaritans since Old Testament times grew to hate one another for political and religious.

[17] Falola, T. (2009) Colonialism and Violence in Nigeria. Indiana University Press, Bloomington, 19.

[18] Falola, T. (2009) Colonialism and Violence in Nigeria. Indiana University Press, Bloomington.

[19] Slemon, S. (1993) Modernism's Last Post. In: Adam, I. and Tiffin, H., Eds., Past the Last Post: Theorizing Post-Colonialism and Post-Modernism, Harvester Wheatsheaf, Hemel Hempstead, 3.

[20] 26 April 2015. www.mikesdonkeys.co.uk

[21] Falola, T. (2009) Colonialism and Violence in Nigeria. Indiana University Press, Bloomington, 185.

[22] Grundy, K.W. (1966) African Explanations of Underdevelopment: The Theoretical Basis for Political Action. The Review of Politics, 28, 75. http://dx.doi.org/10.1017/S0034670500005945

[23] It should be noted that only John's gospel brings this event much earlier in Jesus' ministry in chapter 2. 